\title{
Stylosanthes rostrata (Leguminosae), a New Combination from Argentina and Uruguay
}

\author{
Ricardo O. Vanni \\ Instituto de Botánica del Nordeste, Casilla de Correo 209, 3400 Corrientes, Argentina. \\ gvanni@agr.unne.edu.ar
}

Abstract. As part of the revision of the genus Stylosanthes Swartz (Leguminosae) from South America, material from Corrientes, Argentina, described by Burkart as S. gracilis Kunth var. rostrata Burkart, is recognized at species rank as $S$. rostrata (Burkart) Vanni.

Resumen. Durante la revisión del género Stylosanthes Swartz (Leguminosae) para Sudamérica, el material de Corrientes, Argentina, descripto por Burkart como S. gracilis Kunth var. rostrata Burkart, es considerado una especie diferente $S$. rostrata (Burkart) Vanni.

Key words: Argentina, Leguminosae, Stylosanthes, Uruguay.

Stylosanthes gracilis Kunth was broadly interpreted by Burkart (1939) and included four varieties under the name, one of which was $S$. gracilis var. rostrata Burkart. The name $S$. gracilis var. rostrata was later considered by Mohlenbrock (1957) as a synonym of $S$. montevidensis Vogel, but he did not study type material of Burkart's variety or of S. montevidensis. The species was recently considered under the synonymy of $S$. guianensis (Aublet) Swartz var. gracilis (Kunth) Vogel.

Stylosanthes rostrata occurs in northeastern Argentina and Uruguay and is sympatric with S. hippocampoides Mohlenbrock and S. montevidensis. These three species maintain their particular characteristics within the same distributional area. Stylosanthes hippocampoides and $S$. montevidensis have a broader distributional range, occurring from southern Brazil and south into Paraguay, Uruguay, and Argentina.

Stylosanthes rostrata (Burkart) Vanni, comb. et stat. nov. Basionym: Stylosanthes gracilis Kunth var. rostrata Burkart, Darwiniana 3(2): 251. 1939. TYPE: Argentina. Corrientes: Granja de Bella Vista, 18 July 1905, C. Spegazzini \& C. D. Girola 54 [Min. Agr. 14648] (holotype, SI). Figure 1.
Plants perennial, branches prostrate to suberect, with setae and hair incurved, white, short. Leaves trifoliolate; stipules $11 \mathrm{~mm}$, connate to the base or foliate, free in the upper half and then subulate, with setae and scattered curved trichomes; petioles 5$6 \mathrm{~mm}$; leaflets $12-15 \times 2-3 \mathrm{~mm}$, narrowly elliptic, mucronate, apically setose; the lateral ones asymmetric, with the longest terminal; hypophyllus with scattered weak trichomes, evident, with white veins, with dense setae along the nerves, margins jagged with mucronate teeth; epiphyllus with setae. Inflorescences terminal or subterminal, in dense spikes, with up to 8 flowers; bracts similar to stipules, with central lamina ca. $8 \mathrm{~mm}$, bracteoles 2, hyaline at flower bases. Flowers yellow. Fruit with a single article, ca. 6 $\times 3 \mathrm{~mm}$, the lower article rarely developed, with evident longitudinal veins, glabrous, a few thick hairs on the open beak, ca. $1.5 \mathrm{~mm}$, with a slight apical bend.

Distribution and habitat. Stylosanthes rostrata is found in northeastern Argentina (Corrientes) and in Uruguay in humid sandy soils.

Comments. Stylosanthes rostrata is similar to $S$. hippocampoides, differing mainly in the article beak of the fruit, which is more incurved in S. hippocampoides. Stylosanthes rostrata differs from S. montevidensis in the latter species having plants of juncoid aspect, with fewer leaves, and fruit with a strongly uncinate beak with yellowish hairs in the concavity.

Additional specimens examined. URUGUAY. Colonia: Riachuelo, Feb. 1930, Herter 85562 (M, NY); La Colonia (río de la Plata), Feb. 1918, L. Hauman s.n. (BR).

Acknowledgments. Thanks are due to Ernestina Galeano for suggestions that improved the manuscript.

Literature Cited

Burkart, A. 1939. Estudios sistemáticos sobre las Leguminosas-Hedisareas de la República Argentina y regiones adyacentes. Darwiniana 3: 117-302.

Mohlenbrock, R. 1957. A revision of the genus Stylosanthes. Ann. Missouri Bot. Gard. 44: 299-355. 




Figure 1. Stylosanthes rostrata (Burkart) Vanni. —A. Branch. - B. Inflorescence. —C. Fruit. Drawn from the holotype, Spegazzini \& Girola 54 (SI). 